\title{
Effect of High Density Planting on Quality of Curry Leaf (Murraya koenigii Spreng.)
}

\author{
R.P. Jagadeeshkanth ${ }^{1 *}$, R. Sankaranarayanan ${ }^{2}$ and V. Suresh ${ }^{3}$ \\ ${ }^{1}$ (Horticulture), Imayam Institute of Agriculture and Technology, Thuraiyur, Trichy District, \\ Tamil Nadu, India \\ ${ }^{2}$ (Horticulture), Department of fruit crops, Horticultural College and Research Institute, \\ Periyakulam, Theni District, Tamil Nadu, India \\ ${ }^{3}$ (Horticulture), RVS Padmavathy College of Horticultural, Sembatti, Dindugul district, \\ Tamil Nadu, India \\ *Corresponding author
}

A B S T R A C T

Keywords

HDP, Curry leaf,

Leaf yield and quality.

Article Info

Accepted:

21 October 2017

Available Online:

10 December 2017
A field experiment on effect of high density planting on quality of curry leaf was conducted at Department of Spices and Plantation Crops, Horticultural College and Research Institute, Tamil Nadu Agricultural University, Periyakulam during 2011-13. The experiment was layed out in randomized block design with six treatments. Biometrical observations were made from randomly selected five plants and were subjected to statistical analysis. The result reveled that, among the six level of high density planting registered the highest leaf quality as essential oil content ( 0.156 per cent), crude protein (5.3 per cent), iron content (3.41 per cent), calcium content $(834.55 \mathrm{mg}$ per $100 \mathrm{~g})$ and phosphorous $(0.71$ per cent).

\section{Introduction}

Murraya koenigii, commonly known as curry leaf or kari patta in Indian dialects, belonging to Family Rutaceae which represent more than 150 genera and 1600 species1. Murraya Koenigii is a highly values plant for its characteristic aroma and medicinal value. Curry leaf is originated from Tarai region of Uttar Pradesh (India). It is a perennial nutritious herbal spice crop grown for its aromatic leaves. The crop has been introduced to South India when the Dravidians moved to south with the arrival of Aryans from Persia. Besides, being a spice crop curry leaf plays a major role in the Siddha, Ayurveda and Unani systems of medicine due to its wide range of medicinal properties. Fresh leaves of curry leaves on distillation give a yellow coloured volatile oil with a strong spicy odour, pungent and clove like taste (Goudra et al., 1992). The essential oil has very good antibacterial and antifungal activity. The seeds of curry leaf are having some insecticidal or repellant properties (Balaji, 1988). Curry leaf is extensively used in South India and Sri Lanka for its authentic flavor (Gowdra, 1990). In Tamil Nadu it is cultivated on commercial 
scale in Coimbatore, Erode, Madurai, Salem and Trichirapalli districts. The importance of plant population (PP) as a factor determining growth and yield has been well established for the major curry leaf production areas.

\section{Materials and Methods}

A field experiment on effect of High Density Planting on yield and quality of curry leaf was conducted at Department of Spices and Plantation Crops, Horticultural College and Research Institute, Tamil Nadu Agricultural University, Periyakulam during 2011-13. The experiment was laid out in a randomized block design with six treatments as follows:

Data on leaf yield as leaf quality as essential oil content (per cent), crude protein (per cent), iron content (per cent) and calcium content (mg per $100 \mathrm{~g}$ ) were recorded. The data were subjected to statistics analysis as the method suggested by Panse and Sukhatme (1985).

\section{Results and Discussion}

The effect of plant population on essential oil content of the curry leaf is furnished (Table 1 and Figure 1).

The essential oil content exhibited significant differences among the treatments.

The maximum essential oil content was recorded at spacing of $\mathrm{T}_{3}-0.6 \times 0.9 \mathrm{~m}(0.156$ $\%)$ it was closely followed by $\mathrm{T}_{5}-0.9 \times 1.2 \mathrm{~m}$ $(0.148 \%)$ compared to minimum recorded in $\mathrm{T}_{1}-0.45 \times 0.45 \mathrm{~m}(0.128 \%)$.

The crude protein content exhibited significant differences among the treatments. It ranged from $3.9 \%$ to $5.3 \%$. The maximum crude protein content was recorded at spacing of $\mathrm{T}_{3}-0.6 \times 0.9 \mathrm{~m}(5.3 \%)$ it was closely followed by $\mathrm{T}_{5}-0.9 \times 1.2 \mathrm{~m}(4.8 \%)$ compared to minimum recorded in $\mathrm{T}_{1}-0.45 \mathrm{x}$ $0.45 \mathrm{~m}(3.9 \%)$ followed by $\mathrm{T}_{2}-0.6 \times 0.6 \mathrm{~m}$ $(4.2 \%)$.

The experiment was laid out in a randomized block design with six treatments

\begin{tabular}{|c|l|}
\hline Treatments & \multicolumn{1}{|c|}{ Details } \\
\hline $\mathrm{T}_{1}$ & $0.45 \times 0.45 \mathrm{~m}$ \\
\hline $\mathrm{T}_{2}$ & $0.6 \times 0.6 \mathrm{~m}$ \\
\hline $\mathrm{T}_{3}$ & $0.6 \times 0.9 \mathrm{~m}$ \\
\hline $\mathrm{T}_{4}$ & $0.9 \times 0.9 \mathrm{~m}$ \\
\hline $\mathrm{T}_{5}$ & $0.9 \times 1.2 \mathrm{~m}$ \\
\hline $\mathrm{T}_{6}$ & $1.2 \times 1.2 \mathrm{~m}$ \\
\hline
\end{tabular}

Table.1 Effect of HDP on essential oil content (per cent) and calcium content (mg per 100g) of curry leaf

\begin{tabular}{|l|c|c|}
\hline Treatments & Essential oil (per cent) & Calcium content (mg per 100g) \\
\hline $\mathrm{T}_{1}$ & 0.128 & 780.65 \\
\hline $\mathrm{T}_{2}$ & 0.132 & 810.68 \\
\hline $\mathrm{T}_{3}$ & 0.156 & 834.55 \\
\hline $\mathrm{T}_{4}$ & 0.137 & 817.54 \\
\hline $\mathrm{T}_{5}$ & 0.148 & 832.14 \\
\hline $\mathrm{T}_{6}$ & 0.144 & 826.34 \\
\hline Mean & 0.141 & 816.38 \\
\hline SEd & 0.003 & 11.74 \\
\hline CD $(\mathbf{0 . 0 5})$ & 0.006 & 25.04 \\
\hline
\end{tabular}


Fig.1 Effect of planting density on crude protein content (per cent) and Iron content (per cent) in curry leaf

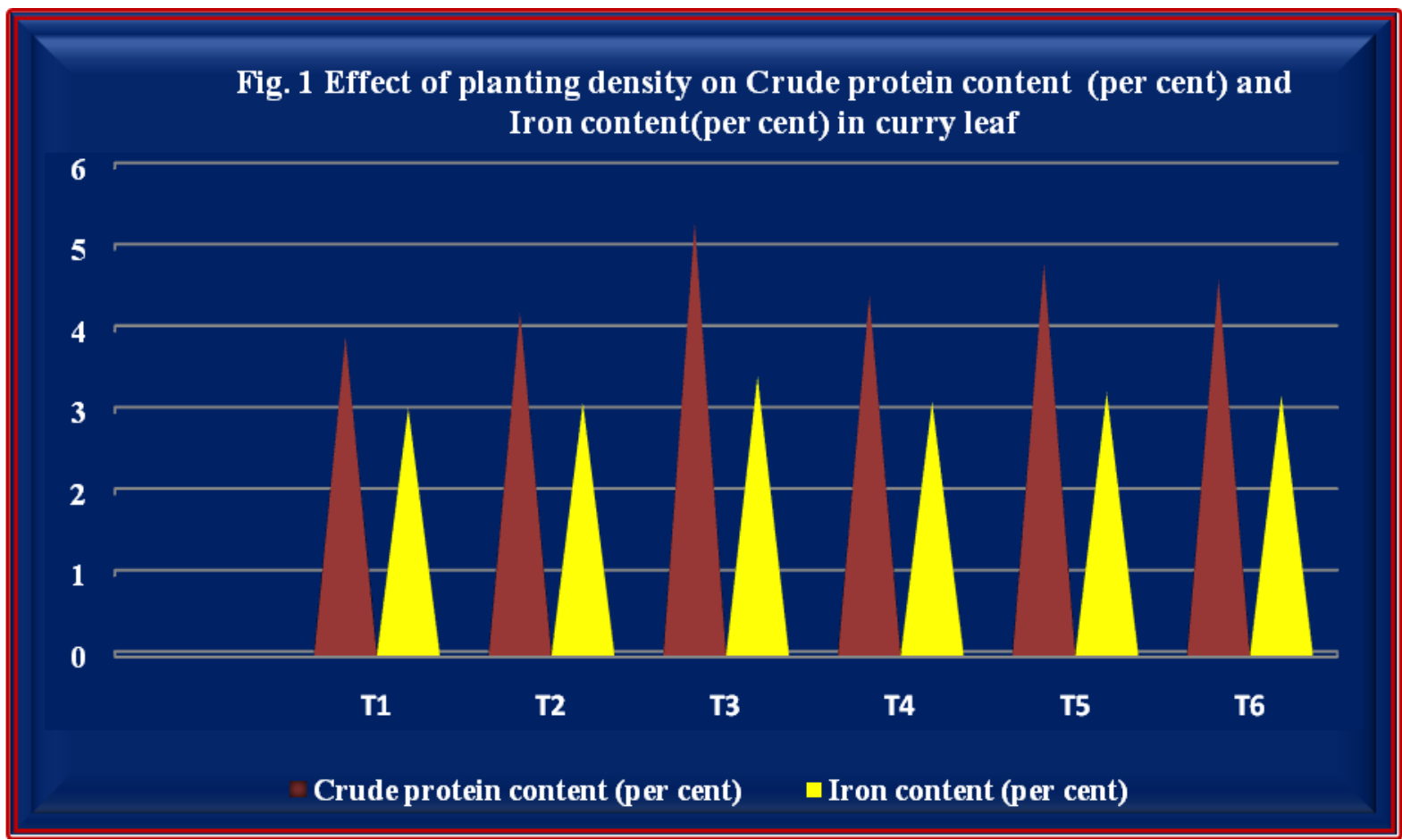

The maximum iron content was recorded at spacing of $\mathrm{T}_{3}-0.6 \times 0.9 \mathrm{~m}(3.41 \%)$ it was closely followed by $\mathrm{T}_{5}-0.9 \times 1.2 \mathrm{~m}(3.21 \%)$ and $\mathrm{T}_{6}-1.2 \times 1.2 \mathrm{~m}(3.18 \%)$ compared to minimum recorded in $\mathrm{T}_{1}-0.45 \times 0.45 \mathrm{~m}$ (3.02\%) followed by $\mathrm{T}_{2}-0.6 \times 0.6 \mathrm{~m}$ (3.09 $\%)$. The calcium content exhibited significant differences among the treatments. It ranged from780.65 mg/100g to $834.55 \mathrm{mg} / 100 \mathrm{~g}$. The maximum calcium content was recorded at spacing of $\mathrm{T}_{3}-0.6 \times 0.9 \mathrm{~m}(834.55 \mathrm{mg} / 100 \mathrm{~g})$ it was closely followed by $\mathrm{T}_{5}-0.9 \times 1.2 \mathrm{~m}$ $(832.14 \mathrm{mg} / 100 \mathrm{~g})$ and $\mathrm{T}_{6}-1.2 \times 1.2 \mathrm{~m}$ $(826.34 \mathrm{mg} / 100 \mathrm{~g})$ compared to minimum recorded in $\mathrm{T}_{1}-0.45 \times 0.45 \mathrm{~m} \quad(780.65$ $\mathrm{mg} / 100 \mathrm{~g})$ followed by $\mathrm{T}_{2}-0.6 \times 0.6 \mathrm{~m}$ $(810.68 \mathrm{mg} / 100 \mathrm{~g})$.

In the present study, among the six level of density, high density planting at $0.6 \times 0.9 \mathrm{~m}$ $\left(T_{3}\right)$ recorded significantly higher quality of curry leaf. The obtained results showed that plant density has significant effect on the percentage and yield of the basil essential oil (Seyed Abbas Mirjalili and Elahe Poorazizi, 2014). The density factor becomes significant on the percentage of the essential oil at $1 \%$ level and also becomes significant on the yield of it at $5 \%$ level. These results are due to the fact that at low density, the competition between the plants reduced and hence, each plant has more space and produces more leaves. Therefore the rate of produced essential oil increases at low densities. Thus, by increasing the plant density the yield of essential oil increases. Moreover, it should not be neglected that increase in plant density will also affect the dry weight that, in turn, could affect the yield of essential oil. Also, the essential oil ratio of plants under extra light is more than the ratio for the plants of ordinary light and biosynthesis of the essential oil is highly dependent on light conditions. Hence, by increasing the rate of biosynthesis, production of the extract could in overall increase in thyme (Letchamo and 
Gosselin, 1995). In this research, the yield of essential oil has been achieved at low density (40 plants in $\mathrm{m}^{2}$ ) and the results could be interpreted in Ocimum (Arabaci and Bayram, 2004).

Hence, it could be concluded that high density planting $\mathrm{T}_{3}(0.6 \times 0.9 \mathrm{~m})$ would results in better quality viz., Essential oil, crude protein, iron and calcium content in curry leaf. Further, the density of planting which would facilitate the cultivation of curry leaf under high density of planting.

\section{References}

Arabaci O, Bayram E. 2004. The effect of nitrogen fertilization and different plant densities of some agronomic and technologic characteristic of Ocimum basilicum L. (Basil). Journal of Agronomy, 1, 255-262.

Balaji, B.R., 1988. Investigations on nutrition of curry leaf. M.Sc., (Agri.) Thesis, University of Agricultural Sciences, Bangalore.
Goudra, B.K. H and B.B. Madalagiri. 1992. Effect of nitrogen nutrition on yield and yield component of curry leaf (Murraya koenigii Spreng). Indian Cocoa, Arecanut Spices J., 16(2): 66-68.

Gowdra, K.H.B. 1990. Curry leaf (Murraya koenigii Spreng). Production in relation to nitrogen nutrition and growth regulators. M.Sc., (Agri) Thesis, University of Agricultural Sciences, Dharwad.

Letchamo W, Xu HL, Gosselin A. 1995. Photosynthesis potential of Thymus vulgaris selections under two light regimes and three soil water levels. Scientia Horticulturae, 62, 89-101.

Panse, V.G. and P.V. Sukhatme. 1985. Statistical methods for agricultural works. Fourth Edn, ICAR, New Delhi.

Seyed Abbas Mirjalili and Elahe Poorazizi. 2014. Effects of density and cultivation method on ratio and yield of essential oil in basil (Ocimum basilicum L.). International Journal of Agronomy and Agricultural Research. 4(4): 117-123.

\section{How to cite this article:}

Jagadeeshkanth, R.P., R. Sankaranarayanan and Suresh, V. 2017. Effect of High Density Planting on Quality of Curry Leaf (Murraya koenigii Spreng.). Int.J.Curr.Microbiol.App.Sci. 6(12): 2861-2864. doi: https://doi.org/10.20546/ijcmas.2017.612.333 